\title{
BLOOD AND TISSUE SELENIUM CONCENTRATIONS IN CALVES TREATED WITH INORGANIC OR ORGANIC SELENIUM COMPOUNDS - A COMPARISON
}

\author{
L. PAVLATA, J. ILLEK, A. PECHOVÁ \\ Clinic of Diseases of Ruminants, Faculty of Veterinary Medicine, University of Veterinary and Pharmaceutical
} Sciences, Brno, Czech Republic

Received October 25, 2000

Accepted February 7, 2001

Abstract

Pavlata L., J. Illek, A. Pechová:Blood and Tissue Selenium Concentrations in Calves Treated with Inorganic or Organic Selenium Compounds - a Comparison. Acta Vet. Brno 2001, 70: 19-26.

Selenium concentrations were investigated in 5 calves treated parenterally with inorganic selenium (Group II), 5 calves treated orally with organic selenium (Group III), and 5 untreated control calves (Group I). Blood samples for analyses were collected at the beginning and at the end of the treatment period and tissue samples (liver, kidney, striated muscle, myocardium) after slaughter. Selenium was determined in the samples after microwave mineralisation using the hydride technique of AAS. Both treated groups showed highly significant increases in whole blood selenium concentrations (Group II from $53.4 \pm 10.5$ to $75.9 \pm 4.0 \mu \mathrm{g} .1^{-1}$; Group III from $70.25 \pm$ 12.07 to $\left.127.5 \pm 16.7 \mu \mathrm{g} . \mathrm{l}^{-1}\right)$. The comparison of tissue concentrations showed highly significant differences $(P<0.01)$ in the liver $\left(213.3 \pm 56.8,206.5 \pm 36.2\right.$ and $424.7 \pm 88.4 \mu{\mathrm{g} . \mathrm{kg}^{-1}}^{-1}$ wet tissue for the Groups I, II, and III, respectively), striated muscles $(92.4 \pm 29.2,81.4 \pm 12.1$, and $263.4 \pm$ $47.4 \mathrm{\mu g} \cdot \mathrm{kg}^{-1}$ wet tissue for the Groups I, II and III, respectively), and myocardium (121.5 \pm 31.8 , $108.3 \pm 9.6$, and $251.4 \pm 51.0 \mu \mathrm{g} . \mathrm{kg}^{-1}$ wet tissue for the Groups I, II and III, respectively) not only between Groups I and II, but also between Groups II and III. The among-group differences in selenium concentrations in the kidney $\left(991.9 \pm 49.1,960.6 \pm 36.3\right.$, and $1050.5 \pm 336.8 \mu \mathrm{g}_{\mathrm{kg}} \mathrm{kg}^{-1} \mathrm{wet}^{-}$ tissue in the Groups I, II and III, respectively) were nonsignificant. It is apparent that oral administration of organic selenium resulted in higher tissue concentrations than parenteral administration of inorganic selenium. Highly significant $(P<0.01)$ correlations were found between selenium concentrations in the liver and striated muscles, in the liver and the myocardium, and in striated muscles and the myocardium $(r=0.78,0.85$, and 0.94 , respectively). No relations were found between selenium concentrations in the kidney and other tissues. Highly significant $(\mathrm{P}<0.01)$ correlations were also between the concentrations of selenium in the blood and in the liver, striated muscles, and the myocardium $(\mathrm{r}=0.85,0.80$, and 0.77 , respectively).

Cattle, liver, striated muscle, myocardium, kidney

Recent knowledge of biological effects of trace elements has prompted studies of their effects on animal health and performance. The importance of such studies is enhanced by the use of trace elements as feed additives as a replacement for antibiotic and hormonal growth stimulants. Considerable attention in this respect is paid to selenium. The principal source of this element for animals are plants. Groce et al. (1995), who studied correlations between the contents of essential trace elements in soil, forages, and blood, found a highly significant correlation coefficient $(r=0.96)$ for selenium. Availability of soil selenium to plants depends on soil acidity, structure and degree of aeration. Availability of oxidised forms is higher than that of the reduced form which remains undissolved in the soil. Selenium is incorporated into plant tissues mostly in the form of selenomethionine present in the protein component of grain. Hence, the content of selenium in grain closely correlates with the content of protein (Mahan 1999). Further factors influencing the content of selenium in plants include the vegetation phase,

Address for correspondence:

MVDr. Leoš Pavlata

Clinics of Diseases of Ruminants, Faculty of Veterinary Medicine

y and Pharmaceutical Sciences Brno

Palackého 1-3, 61242 Brno, Czech Republic
Phone: +420541562407

Fax: +420549248841

http://www.vfu.cz/acta-vet/actavet.htm 
diluting effects of long-lasting rains, season, and fertilisation with sulphur (Ammerman and Miller 1975). Our earlier observations have shown that selenium deficiency in the Czech Republic is a serious and topical problem. Tests of blood samples collected from 326 cattle in 30 herds demonstrated insufficient or marginal saturation with selenium in 64 percent of the probands (Pavlata et al. 2000a). Tests carried out in slaughter cattle revealed selenium deficiency in more than 80 percent of the animals; the deficiency was observed more frequently in heifers and bulls than in cows (Pavlata et al. 2000b). Illek et al. (1999), who tested ten herds of high-producing Holstein cows, found selenium deficiency in dry cows in eight and in lactating cows in four of them. The results of the above studies emphasise the necessity of monitoring of the selenium status and of supplementation in animals showing deficiency. The major source of selenium used world-wide is sodium selenite. Most, but not all, problems resulting from insufficient supply of selenium can be solved by administration of selenite. Therefore increased attention of researchers is paid to organic selenium compounds. One of the supplementation forms used recently are yeast which incorporate selenium into amino acids. The organic form is more suitable for metabolic transformation (Mahan 1999). In the Czech Republic, animals showing selenium deficiency are most frequently treated with a local drug containing inorganic selenium and vitamins in a formula for parenteral administration. Therefore this drug was included into our experiment. Its objectives were a) to compare the effects of administration to calves of inorganic and organic selenium forms at recommended dosage in terms of blood and tissue selenium concentrations; $b$ ) to study the tissue distribution of selenium and to select tissues most suitable for the monitoring of the selenium status.

\section{Materials and Methods}

Fifteen one-month-old ( \pm 4 days) Holstein calves, 55 to $65 \mathrm{~kg}$ in weight, born by cows of a single herd were selected for the experiment. The calves were housed in individual outdoor sheds, had free access to a selenium-free starter diet and received 21 of milk per day up to the age of 2 months. The experimental period was 2 months. The calves were randomly divided into three groups of five. Group I were controls. Group II was treated (the $1^{\text {st }}$ day of the experiment) intramuscularly with inorganic selenium and vitamin E (SELEVIT inj. ad us. vet., natrii selenis anhydricus $2.2 \mathrm{mg}$, tocoferoli acetas $25 \mathrm{mg}$ per $1 \mathrm{ml}$ ) at the dose of $20 \mathrm{ml}$ split to two injection sites in the neck region; the treatment was repeated one week later. The total amount of received net selenium was $40 \mathrm{mg}$; Group III was fed a starter diet supplemented with yeast-bound selenium (SEL-PLEX, Alltech, selenium $1000 \mathrm{mg} \cdot \mathrm{kg}^{-1}$ ) at the recommended concentration of $0.3 \mathrm{mg}$ selenium per $1 \mathrm{~kg}$ throughout the experimental period. At the mean feed consumption of $2 \mathrm{~kg}$ per animal per day the calves of this group received a total of $36 \mathrm{mg}$ of selenium per animal. Blood samples for the determination of selenium concentration were collected by puncture of $\mathrm{v}$. jugularis into disposable heparinised tubes at the beginning and at the end of the experiment. The calves were slaughtered within two subsequent days and samples of liver, striated muscle, myocardium and renal cortex tissues were collected for analyses.

The blood and tissue samples were mineralised by microwave digestion in a closed system in the presence of nitric acid and hydrogen peroxide using the MILESTONE MLS-1200 apparatus. The dried mineralised product was dissolved in water and reduced by addition of hydrochloric acid. Selenium was then determined using the hydride technique of AAS in the UNICAM 939 AA spectrometer. The results are expressed in $\mu \mathrm{g} . \mathrm{l}^{-1}$ of blood, or $\mu \mathrm{g} \cdot \mathrm{kg}^{-1}$ of wet tissue.

Correlation coefficients were calculated and results were processed by $t$-test after $F$-test for equality of variation using the EXCEL and STAT plus software.

\section{Results}

Blood selenium concentrations in the three groups at the beginning and after the end of selenium supplementation are shown in Fig. 1. No virtual difference between the initial and the final blood selenium concentrations was observed in Group I (69.21 \pm 11.22 vs. $68.42 \pm$ $10.7 \mu \mathrm{g} . \mathrm{l}^{-1}$ ). The concentrations of selenium increased in Group II (inorg. Se) from $53.4 \pm$ $10.5 \mu \mathrm{g} . \mathrm{l}^{-1}$ to $75.9 \pm 4.0 \mu \mathrm{g} . \mathrm{l}^{-1}$ and in Group III (organic Se) from $70.25 \pm 12.07$ to $127.5 \pm$ $16.7 \mu \mathrm{g} . \mathrm{l}^{-1}$. The increases were highly significant in both the groups. 
The results of analyses of tissue samples and significance of differences are given in Tables 1 and 2, respectively. The highest selenium concentrations were found in the kidney, followed by the liver and muscles. Highly significant differences were found for selenium concentrations in the liver, striated muscles, and the myocardium between Groups I and II and Groups II and III. No significant among-group differences were found in selenium concentrations in the

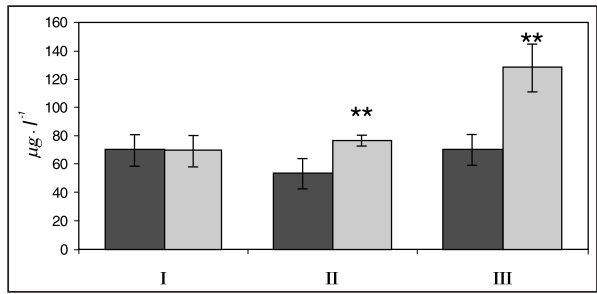

Fig. 1: Selenium concentrations (mean \pm S.D.) in whole blood of the individual calf groups (I, II and III) at the beginning and after the experiment $(* * P<0.01)$. kidney. Positive correlations were found among the concentrations of selenium in the blood, the liver, striated muscles and the myocardium. No correlations were found for the concentrations of selenium in the kidney and in any of the remaining tissues. The respective correlation coefficients are shown in Table 3.

Table 1

Selenium concentrations $\left(\mu \mathrm{g} . \mathrm{kg}^{-1}\right)$ in tissues of slaughtered calves of the individual groups

\begin{tabular}{|l|c|r|r|r|r|}
\hline & & Liver & Kidney & Muscle & Myocardium \\
\hline Group I & mean & 213.3 & 991.9 & 92.4 & 121.5 \\
\hline & S.D. & 56.8 & 49.1 & 29.2 & 31.8 \\
\hline Group II & mean & 206.5 & 960.6 & 81.4 & 108.3 \\
\hline & S.D. & 36.2 & 36.3 & 12.1 & 9.6 \\
\hline Group III & mean & 424.7 & 1050.5 & 263.4 & 251.4 \\
\hline & S.D. & 88.4 & 336.8 & 47.4 & 51.0 \\
\hline
\end{tabular}

Table 2

Significance of among-tissue differences in selenium concentrations (- non-significant; ** $P<0.01$ )

\begin{tabular}{|l|c|c|c|c|}
\hline & Liver & Kidney & Muscle & Myocardium \\
\hline Group I : Group II & - & - & - & - \\
\hline Group I : Group III & $* *$ & - & $* *$ & $* *$ \\
\hline Group III : Group II & $* *$ & - & $* *$ & $* *$ \\
\hline
\end{tabular}

Table 3

Correlation coefficients $(\mathrm{r})$ for selenium concentrations in various samples including their significance $(* * P<0.01)$

\begin{tabular}{|l|c|c|c|c|c|}
\hline & Blood & Liver & Kidney & Muscle & Myocardium \\
\hline Blood & 1 & $0.85^{* *}$ & 0.16 & $0.80^{* *}$ & $0.77^{* *}$ \\
\hline Liver & & 1 & 0.38 & $0.78^{* *}$ & $0.85^{* *}$ \\
\hline Kidney & & & 1 & 0.07 & 0.01 \\
\hline Muscle & & & & 1 & $0.94^{* *}$ \\
\hline Myocardium & & & & & 1 \\
\hline
\end{tabular}

\section{Discussion}

The administration of inorganic or organic selenium to calves resulted in a highly significant increase in the concentration of blood selenium. In terms of absolute values, the concentration of blood selenium was markedly higher in Group III receiving organic 
selenium. The mean blood selenium concentrations in Group II and Group III rose by $42 \%$ and $82 \%$, respectively. It can be concluded that long term oral administration of recommended dose of organic selenium resulted in markedly higher blood selenium concentrations than parenteral administration of an inorganic selenium-containing drug used currently for the therapy of selenium deficiency. Apart from the irrelevant decrease by $1 \%$, the blood selenium concentration in Group I remained constant throughout the experimental period. Considering the reference value of $100 \mu \mathrm{g} .1^{-1}$, corresponding to adequate selenium supply in cattle (Van Saun 1990; Fisher et al. 1995; Pavlata et al. 2000), the selenium status of all the calves at the beginning of the experiment (mean $64.3 \pm$ 13.1, range 43 - $84 \mu \mathrm{g} . .^{-1}$ ), and in Groups I and II also at its end, must be assessed as deficient or marginal. The lower initial mean value in Group II was due to random allotment of two calves with the lowest blood selenium concentrations. The unchanging blood selenium concentration in Group I is indicative of a constant, but insufficient, supply of selenium to the animals fed the non-supplemented diet.

Increasing attention is paid world-wide to the comparison of effects of organic and inorganic selenium. Differences in the increase of blood selenium in animals treated for 8 weeks with sodium selenite or selenium yeast at equal doses of $0.2 \mathrm{ppm}$ were reported by Malbe et al. (1995). Mean concentrations of blood selenium rose from $5.6 \mu \mathrm{g} . \mathrm{l}^{-1}$ to 167 $\mu \mathrm{g} . \mathrm{l}^{-1}$ and $91 \mu \mathrm{g} . \mathrm{l}^{-1}$ in the animals treated with selenium yeast and sodium selenite, respectively. The corresponding ratio of biological availability for organic and inorganic selenium was 1.9:1. Ortm an et al. (1999) treated experimental groups with sodium selenite, sodium selenate, or selenium yeast at equal doses of $2 \mathrm{mg}$ for 3 months. Whole blood and blood plasma concentrations in the animals treated with organic selenium were significantly higher than in any of the groups receiving inorganic selenium. The difference between the groups receiving inorganic selenium was non-significant. The same results were reported by Ortman and Pehrson (1999) who arranged a similar experiment and measured selenium concentrations in whole blood, blood plasma, and milk of dairy cows. Illek et al. (2000) compared whole blood selenium concentrations in pastured beef heifers receiving either selenium yeast or sodium selenite for two months. Their conclusions were consistent with those of the above authors.

The results of our experiment have extended the current knowledge on effects of long-term oral administration of yeast-bound selenium and double administration of approximately the same dose of inorganic selenium on the selenium status. The higher efficacy of organic selenium was confirmed also by results of analyses of selected tissues. The concentrations in Group II were almost identical with those in Group I and demonstrated that parenteral administration of inorganic selenium had only a minimum effect on tissue reserves. Occasional increases observed after the treatment were followed by rapid decreases and the concentrations at slaughter were low. It can therefore be concluded that, in terms of longrange effects, such treatment failed to improve the selenium status. This was evident also from the absence of differences in tissue selenium concentrations between selected calves of Groups I and II with approximately the same initial blood selenium concentrations. Although the parenteral treatment with inorganic selenium resulted in a significant increase in blood selenium concentrations, tissue concentrations and the overall selenium status were lower than in the calves treated orally with organic selenium. The highly significant differences in selenium concentrations in the liver, striated muscles and myocardium between the control group and the groups receiving organic selenium, as well as between the groups receiving organic and inorganic selenium demonstrate the higher efficacy of organic selenium also in terms of tissue concentrations. Similar results were published by Ortman and Pehrson (1997) as well as Knowles et al. (1999) who investigated blood, liver and milk selenium concentrations in cows receiving selenium yeast. 
Any comparison of data on tissue concentrations as published by different authors is difficult, because their results are expressed in different units and their opinions on the suitability of various tissues for the assessment of selenium status are controversial. V an Vleet (1975) examined tissues of slaughtered normal weaned calves and found the following selenium wet tissue concentrations: liver - $0.12 \mathrm{ppm}$, kidney cortex - $0.63 \mathrm{ppm}$, muscles - 0.05 ppm. Salisbury et al. (1991) in their investigations of selenium concentrations in organs of slaughtered animals found $280 \mu \mathrm{g} . \mathrm{kg}^{-1}$ and $920 \mu \mathrm{g} . \mathrm{kg}^{-1}$ in bovine liver and kidney tissues, respectively. Stowe and Herdt (1992) studied dependence of selenium concentrations in blood serum on age in various animal species and reported the ranges 50 to $80 \mathrm{ng}^{-\mathrm{ml}^{-1}}$ for calves and lambs and 70 to $100 \mathrm{ng} \cdot \mathrm{ml}^{-1}$ for adult cattle, while the concentrations in liver tissue varied between 1200 and $2000 \mathrm{ng} \cdot \mathrm{kg}^{-1}$ dry matter irrespective of the age and species of animals. Zach ara et al. (1993) in their studies of effects of various doses of selenium in feeds on tissue concentrations in lambs found for animals receiving the basic amount of selenium the highest concentrations in kidneys $\left(1320 \mu \mathrm{g} . \mathrm{kg}^{-1}\right.$ wet tissue $)$ and the lowest in striated muscles (30 $\mu \mathrm{g} \cdot \mathrm{kg}^{-1}$ wet tissue). Liver, lung, and spleen concentrations ranged between 140 and $180 \mu \mathrm{g} \cdot \mathrm{kg}^{-1}$. In their study of selenium concentrations in foetal livers and kidneys, Abdelrahman and Kincaid (1993) demonstrated an increase in liver tissue in the period between pregnancy days 145 and 195 and a subsequent decrease in the period between pregnancy days 195 and 245, while the kidney concentrations remained constant. Mee et al. (1994), who studied effects of selenium and iodine status on the course of parturition and state of health of calves, considers kidney selenium concentrations lower than $5.06 \mu \mathrm{mol} . \mathrm{kg}^{-1}$ as indicator of selenium deficiency. Zust et al. (1996) assessed the selenium status of calves on the basis of blood plasma and liver concentrations; in their view, marginal concentrations are $300 \mu \mathrm{g} . \mathrm{kg}^{-1}$ of fresh liver tissue and $30 \mu \mathrm{g} . \mathrm{l}^{-1}$ of blood plasma. Liver and kidney concentrations of selenium were used as indicators of selenium status within etiologic studies of heart malformations in calf foetuses by Orr and Blakley (1997).

This short survey shows that the liver and kidney are used most frequently in the assessment of selenium status. The distribution pattern found in our experiments was consistent with the data of other authors although absolute values are different. Our investigations, too, have confirmed that the highest concentrations are to be found in the kidney, followed by the liver and striated muscles. However, the kidney tissue is apparently less suitable for the monitoring of selenium status in supplementation experiments. Although the concentrations were high, they did not increase in the animals fed diets supplemented with either inorganic or organic selenium. This finding is consistent with the data published by Zachara et al. (1993) who fed lambs a diet supplemented with graded doses of selenium and found a linear increase of selenium concentrations in the liver and lung, but not in the kidney. The spleen, myocardium and striated muscles responded by an increase only in lambs receiving higher doses of selenium. Another reason for refusing the kidney as a matrix for the assessment of selenium status is the lack of significant correlations between the selenium concentrations in the kidney on the one hand, and in the blood, the liver, and striated muscles on the other hand.

The high correlation between blood and liver selenium concentrations $(r=0.85)$ indicates that the two matrices are suitable for the assessment of selenium status. Blood and selenium concentrations were determined also by V an Saun et al. (1989) in their study of the dam foetus relation. Mean in foetal liver and blood serum concentrations were $2140 \mu \mathrm{g}^{\mathrm{kg}} \mathrm{g}^{-1} \mathrm{dry}$ matter and $21.4 \mathrm{ng} \cdot \mathrm{ml}^{-1}$, respectively. The corresponding values for dams were $950 \mathrm{mg} . \mathrm{kg}^{1}$ and $44 \mathrm{ng} . \mathrm{ml}^{-1}$, respectively. For bovine foetuses, the authors regard as appropriate liver and whole blood selenium concentrations of $2200 \mu \mathrm{g} \cdot \mathrm{kg}^{-1}$ dry matter and $120 \mathrm{ng} \cdot \mathrm{ml}^{-1}$, respectively. Similarly, Kirk et al. (1995) found the determination of selenium 
concentrations in bovine foetal liver and in whole blood of dams suitable for the assessment of selenium status at the herd level. Moreover, their investigations demonstrated higher foetal liver selenium concentrations in dairy cattle than in beef cattle $\left(777 \pm 408 \mu \mathrm{g} . \mathrm{kg}^{-1} \mathrm{vs}\right.$. $443 \pm 38 \mu \mathrm{g} \cdot \mathrm{kg}^{-1}$ ) and a closer correlation between selenium concentrations in the blood and calf liver in beef cattle than in dairy cattle. A highly significant correlation between blood and liver selenium concentrations was found also in our recent study in slaughtered bulls (Pavlata et al. 1999).

Another tissue which is apparently suitable for the monitoring of selenium status in cattle are muscles. The correlations between selenium concentrations in the blood and striated muscles $(r=0.80)$, in the blood and myocardium $(r=0.77)$, in the liver and striated muscles $(\mathrm{r}=0.78)$, and in the liver and myocardium $(\mathrm{r}=0.85)$ were highly significant. These results are consistent with our earlier finding of a highly significant correlation between the concentrations of selenium in the blood and diaphragmatic muscles $(r=0.91)$ (Pavlata et al. 1999). Moreover, supplementation with organic selenium resulted in an increase of selenium concentrations in the liver and myocardium by $100 \%$ and in striated muscles by more than $185 \%$.

\section{Conclusions}

Long term oral administration of organic selenium in the form of selenium yeast resulted in higher blood and tissue concentrations than repeated parenteral administration of recommended therapeutic doses of inorganic selenium. The latter treatment was ineffective in terms of tissue concentrations and induced only a considerably smaller increase of blood concentrations. Taking in concentrations and correlation coefficients, the most suitable materials for the monitoring of selenium status in cattle are the blood, the liver, striated muscles, and the myocardium. On the other hand, the kidney was found unsuitable; although the concentrations were the highest, they remained practically constant even in the calves receiving organic selenium.

\section{Porovnání vlivu anorganické a organické formy selenu na jeho koncentraci v krvi a tkáních telat}

Na 15 telatech rozdělených do 3 skupin po pěti (kontrolní - I, pokusná - II a III) bylo provedeno sledování vlivu parenterálně aplikovaného anorganického selenu (u skupiny II) a perorálně podaného organicky vázaného selenu (skupina III) na jeho krevní a orgánové koncentrace. Obsah selenu v krvi byl stanoven na začátku a při ukončení dotačního pokusu a v orgánech (játra, ledviny, kosterní svalovina, myokard) po poražení telat. Stanovení selenu v krvi i orgánech bylo provedeno po mikrovlnné mineralizaci vzorků hydridovou technikou AAS. U obou pokusných skupin bylo zjištěno vysoce signifikantní zvýšení koncentrace selenu $\mathrm{v}$ plné krvi (u skupiny II z průměrné hodnoty $53,4 \pm 10,5 \mu \mathrm{g} . \mathrm{l}^{-1}$ na 75,9 $\pm 4,0 \mu \mathrm{g} . \mathrm{l}^{-1}$, resp. z hodnoty $70,25 \pm 12,07 \mu \mathrm{g} . \mathrm{l}^{-1}$ na $127,5 \pm 16,7 \mu \mathrm{g} . \mathrm{l}^{-1}$ u skupiny III). Při porovnání orgánových hladin selenu byl zjištěn vysoce průkazný rozdíl $(P<0,01) \mathrm{v}$ koncentraci selenu $\mathrm{v}$ játrech, kosterní svalovině a myokardu mezi skupinou číslo I a III, ale i II a III (při koncentraci selenu v játrech u skupiny I - 213,3 $\pm 56,8$; II - 206,5 \pm 36,2; III$424,7 \pm 88,4 \mu \mathrm{g} . \mathrm{kg}^{-1}$ čerstvé tkáně, v kosterní svalovině u skupiny I - 92,4 $\pm 29,2 ; \mathrm{II}$ - 81,4 $\pm 12,1$; III - 263,4 $\pm 47,4 \mu \mathrm{g} \cdot \mathrm{kg}^{-1}$ čerstvé tkáně a v myokardu u skupiny I - 121,5 \pm 31,8; II $-108,3 \pm 9,6$; III $-251,4 \pm 51,0 \mu \mathrm{g} . \mathrm{kg}^{-1}$ čerstvé tkáně. Obsah selenu v ledvinách nebyl mezi zvíraty jednotlivých skupin průkazně rozdílný (I - 991,9 \pm 49,1; II - 960,6 \pm 36,3; III$1050,5 \pm 336,8 \mu \mathrm{g} . \mathrm{kg}^{-1}$ čerstvé tkáně). Efekt perorálně podaného organicky vázaného selenu tak byl z hlediska vzestupu orgánových hladin výrazně vyšší v porovnání s parenterálnî 
aplikací anorganické formy. Dále bylo provedeno vyhodnocení těsnosti vztahu mezi jednotlivými zjištěnými hodnotami orgánových koncentrací pomocí korelačních koeficientů. Byl zjištěn vysoce průkazný vztah $(P<0,01)$ mezi obsahem Se v játrech a kosterní svalovině, játrech a myokardu a kosterní svalovině a myokardu $(\mathrm{r}=0,78 ; \mathrm{r}=0,85$; $\mathrm{r}=0,94)$. Mezi hodnotami obsahu Se v ledvinách a ostatních tkáních nebyla závislost prokázána. Vysoce průkazná korelace $(P<0,01)$ byla zjištěna i mezi hladinou selenu v krvi a jeho obsahem $v$ játrech, kosterní svalovině a myokardu $(\mathrm{r}=0,85 ; \mathrm{r}=0,80 ; \mathrm{r}=0,77)$.

\section{Acknowledgement}

The work was supported by the Ministry of Education, Youth and Sports of the Czech Republic (Grant No. $161700002 / 1999)$

\section{References}

ABDELRAHMAN, M. M., KINCAID, R. L. 1993: Deposition of copper, manganese, zinc, and selenium in bovine fetal tissue at different stages of gestation. J. Dairy Sci. 76: 3588-3593

AMMERMAN, C. B., MILLER, S. M. 1975: Selenium in ruminant nutrition. A review. J. Dairy Sci. 58: 1561 1577

FISHER, D. D., SAXTON, S. W., ELLIOTT, R. D., BEATTY, J. M. 1995: Effects of selenium sources on Se status of lactating cows. Vet. Clin. Nutr. 2: 68-73

GROCE, A. W., TAYLOR, C. E., PETTRY, D. E., KERR, L. A. 1995: Levels of selenium and other essential minerals in forages, bovine blood and serum relative to soil type. Vet. Clin. Nutr. 2: 146-152

ILLEK, J., PAVLATA, L., PECHOVÁ, A. 2000: Organický selen ve výživě zvírat. In: Agenda 2000: The Food Revolution. Proceedings Alltech's 14th European, Middle Eastern and African Lecture Tour, Brno 23. 2., 31-32

ILLEK, J., PAVLATA, L., PECHOVÁ, A., MATĚJÍČEK, M. 1999: Selenium deficiency in cattle. In: III. Kábrtovy dietetické dny, Proceedings Brno 2. 9., 242-243

KIRK, J. H., TERRA, R. L., GARDNER, I. A., WRIGHT, J. C., CASE, J. T., MAAS, J. 1995: Comparison of maternal blood and fetal liver selenium concentrations in cattle in California. Am. J. Vet. Res. 56: 1460-1464

KNOWLES, S. O., GRACE, N. D., WURMS, K., LEE, J. 1999: Significance of amount and form of dietary selenium on blood, milk, and casein selenium concentrations in grazing cows. J. Dairy Sci. 82: 429-37

MAHAN, D. 1999: Použití př́írodního modelu v nových selenových doplňcích do krmiv. In: Our Industry Under the Microscope...Biotechnology Responds. Proceedings Alltech's 1999 European, Middle Eastern and African Lecture Tour, Brno 25. 2. 1999, 17-24

MALBE, M., KLAASSEN, M., FANG, W., MYLLYS, V., VIKERPUUR, M., NYHOLM, K., SANKARI, S. SUURANTA, K., SANDHOLM, M. 1995: Comparisons of selenite and selenium yeast feed supplements on Seincorporation, mastitis and leukocyte function in Se-defficient dairy cows. Zbl. Vet. Med. A 42: 111-121

MEE, J. F., O'FARRELL, K. J., ROGERS, P. A. M., TRENTI, F. 1994: Effects of parenteral iodine and selenium supplementation on calving performance in trace element - deficient herds. Proceedings 18th World Buiatrics Congress: 26th Congress of the Italian Association of Buiatrics, Bologna, Italy, August 29 - September 2, Volume 1., 649-652

ORR, J. P., BLAKLEY, B. R. 1997: Investigation of the selenium status of aborted calves with cardiac failure and myocardial necrosis. J. Vet. Diagn. Invest. 9: 172-179

ORTMAN, K., ANDERSSON, R., HOLST, H. 1999: The influence of supplements of selenite, selenate and selenium yeast on the selenium status of dairy heifers. Acta Vet. Scand. 40: 23-34

ORTMAN, K., PEHRSON, B. 1997: Selenite and selenium yeast as feed supplements for dairy cows. Zbl. Vet. Med. A 44:373-380

ORTMAN, K., PEHRSON, B. 1999: Effect of selenate as a feed supplement to dairy cows in comparison to selenite and selenium yeast. J. Anim. Sci. 77: 3365-3370

PAVLATA, L., PECHOVÁ, A., ILLEK, J.,MATOULKOVÁ, M., BEČVÁŘ, O., ŠIMKOVÁ, V., KŘǏŽOVÁ, I. 1999: Laboratory diagnostics of selenium deficiency in cattle. In: Mengen- und Spurenelemente, 19. Arbeitstagung, Jena, 547-551

PAVLATA, L., PECHOVÁ, A., ILLEK, J. 2000a: Direct and indirect assessment of selenium status in cattle a comparison. Acta Vet. Brno 69: 281-287

PAVLATA, L., PECHOVÁ, A., ILLEK, J., BEČVÁŘ, O. 2000b: Diagnostics of selenium, zinc and cooper deficiencies in various cattle categories. In: "Effect of Cattle-Herd Health on Production Efficiency." Proceedings of the II. Middle - European Congress for Buiatrics, The High Tatras, May 2000, 149-151

SALISBURY, C. D., CHAN, W., SASCHENBRECKER, P. W. 1991: Multielement concentrations in liver and kidney tissues from five species of Canadian slaughter animals. J. Assoc. Off Anal. Chem. 74: 587-591

STOWE, H. D., HERDT, T.H. 1992: Clinical assessment of selenium status of livestock. J. Anim. Sci. 70: 39283933 
VAN SAUN, R. J. 1990: Rational approach to selenium supplementation essential. Feedstuffs (Jan 15): 15-17 VAN SAUN, R. J., HERDT, T. H., STOWE, H. D. 1989: Maternal and fetal selenium concentrations and their interrelationships in dairy cattle. J. Nutr. 119: 1128-1137

VAN VLEET, J. F. 1975: Retention of selenium in tissues of calves, lambs, and pigs after parenteral injection of a selenium-vitamin E preparation. Am. J. Vet. Res. 36: 1335-1340

ZACHARA, B. A., MIKOLAJCZAK, J., TRAFIKOWSKA, U. 1993: Effect of various dietery selenium (Se) intakes on tissue Se levels and glutathione peroxidase activities in lambs. Zbl. Vet. Med. A 40: 310-318

ZUST, J., HROVATIN, B., SIMUNDIC, B. 1996: Assesment of selenium and vitamin E deficiencies in dairy herds and clinical disease in calves. Vet. Rec. 139: 391-394 